7-1-2015

\title{
The Lyon Declaration on Access to Information and Development
}

Anne Burnett

University of Georgia School of Law, aburnett@uga.edu

\section{Repository Citation}

Burnett, Anne, "The Lyon Declaration on Access to Information and Development" (2015). Presentations. 150.

https://digitalcommons.law.uga.edu/speeches/150

This Conference Proceeding is brought to you for free and open access by the Alexander Campbell King Law Library at Digital Commons @ University of Georgia School of Law. It has been accepted for inclusion in Presentations by an authorized administrator of Digital Commons @ University of Georgia School of Law. Please share how you have benefited from this access For more information, please contact tstriepe@uga.edu. 


\section{THE LYON DECLARATION}

\section{on Access to Information and Development}

\section{UNITED NATIONS}

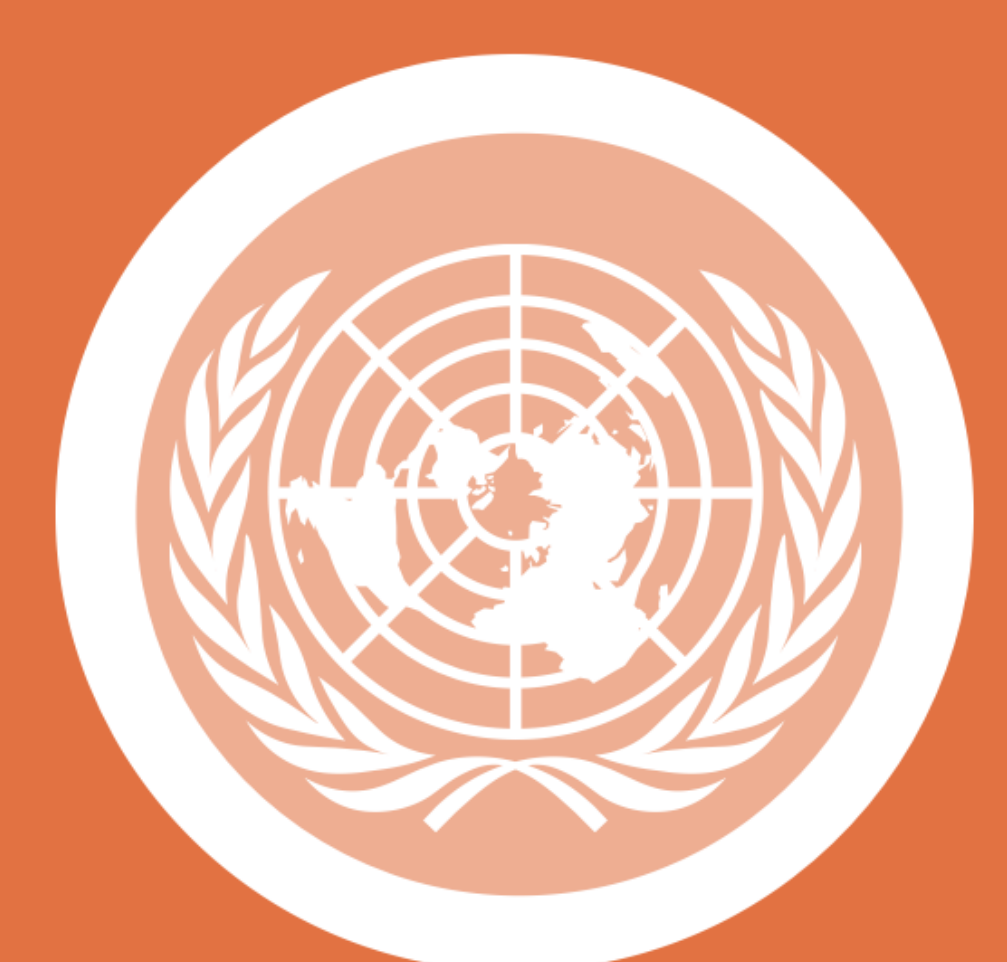

currently drafting its post-

2015 development framework
TWERNATIONALFEDEATION
OFLIBRARYASSOCHATIONS\& istitutions

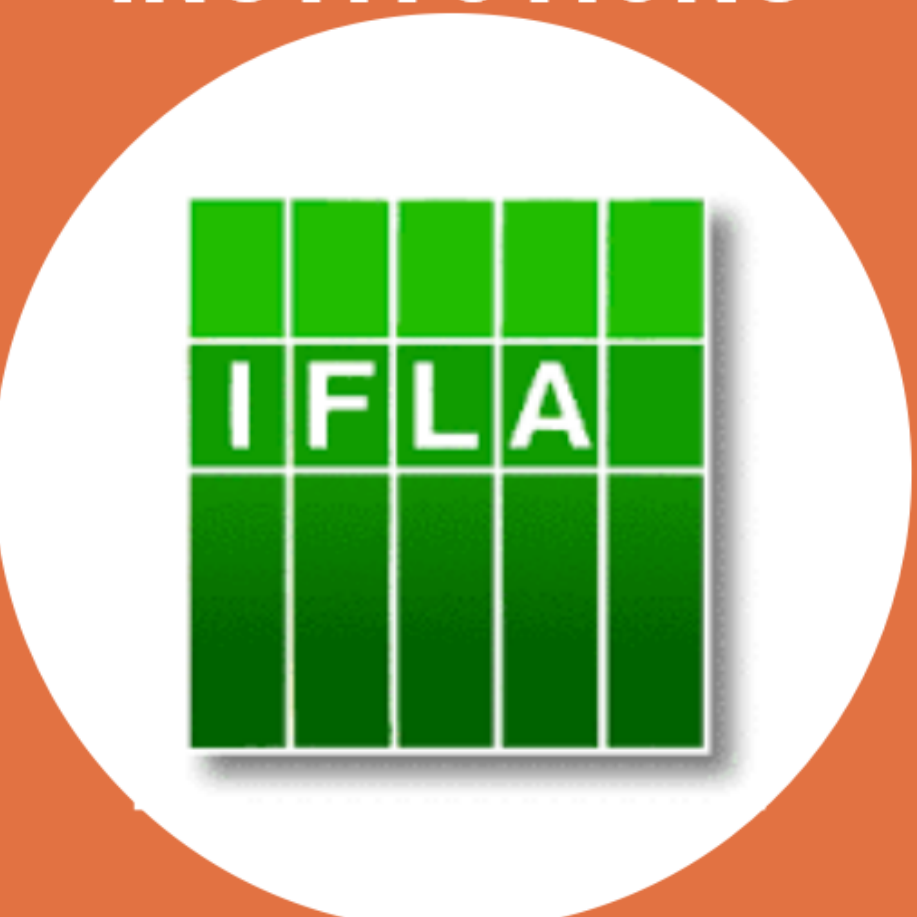

Lyon Declaration urges UN to include access to information framework

\section{SIGNATORIES}

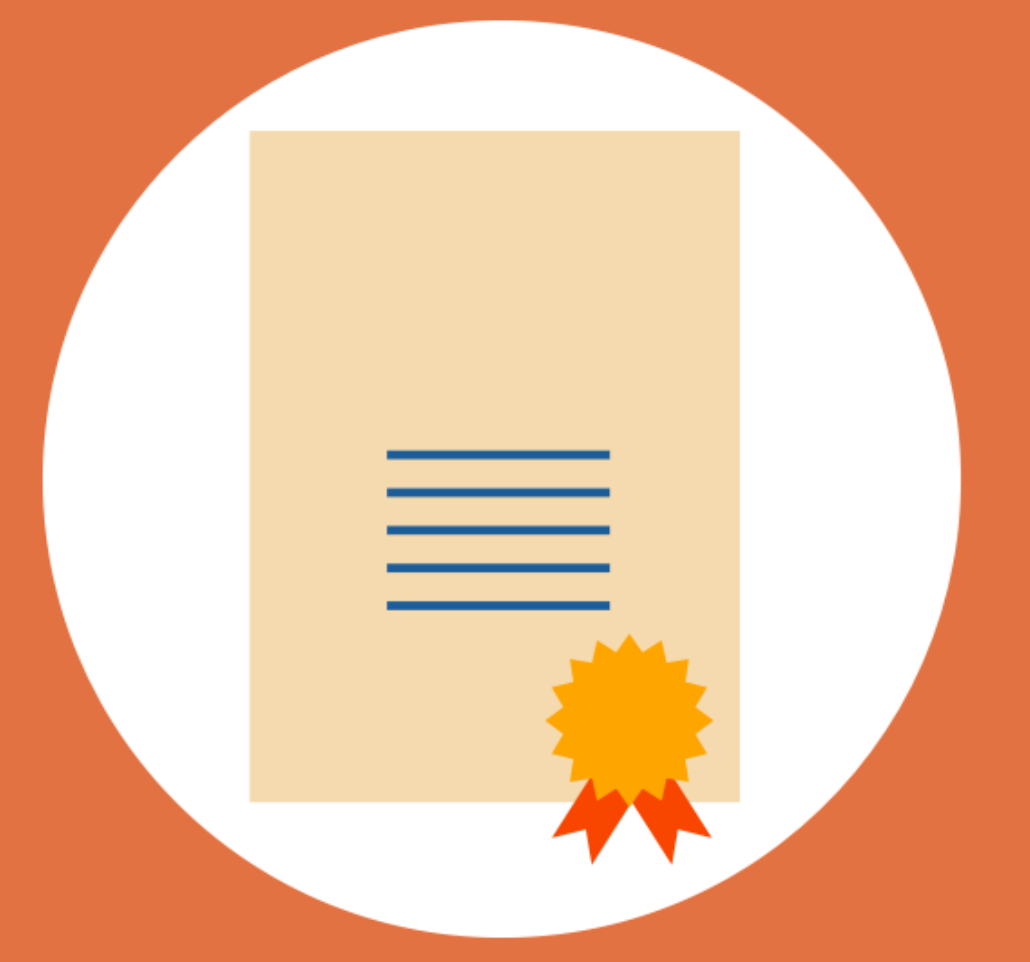

over 540 institutions and associations have signed the Lyon Declaration so

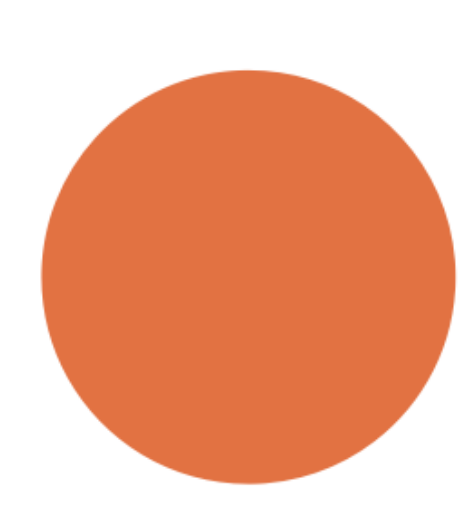

he UN's Millennium Development Goals set targets, by disease lack of adequate shelter and exclusion - while

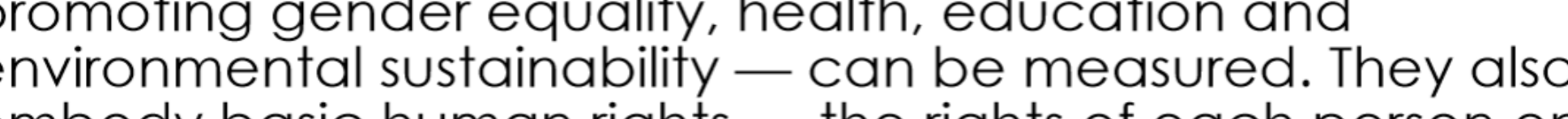
the planet to health education shelter and security. The MDGs conclude in 2015, and the UN is working on its

The High Level Panel on the Post-2015 Development ocus Area Report all identified the crucial role of access

After many months of negotiations following the conclusion sthe "Zero Draft" which will form the basis for discussion during the September. Access to information remains within the Zero Draft IFLA has submitted recommended additions and revisions to the proposed draft.

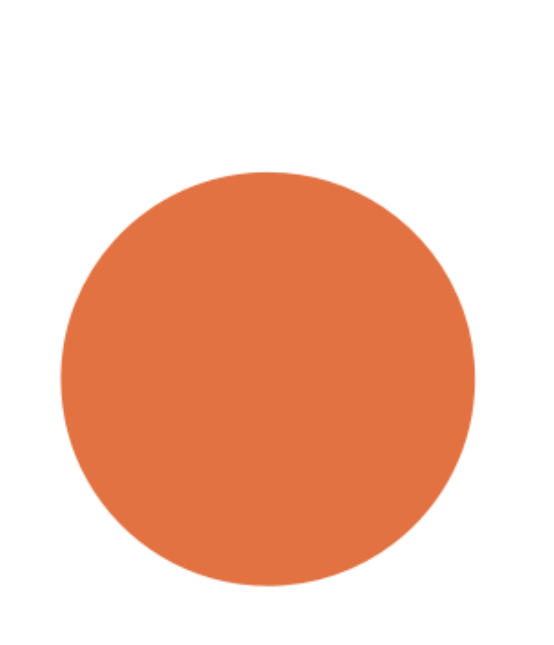

IFLA is working with the international library community-as well as civ society and member states-to ensure that crucial elements such as Agenda. The Lyon Declaration, launched in August 2014 , serves as
advocacy document calling upon UN Member States to make an

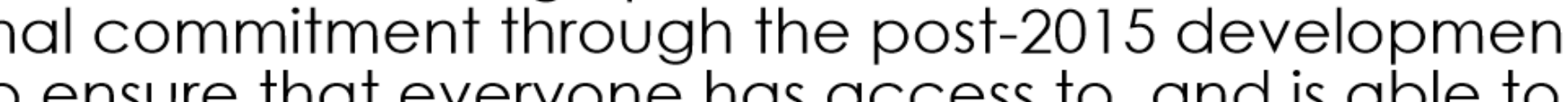
understand, use and share the information that is necessary to Lyon Declaration Principles: Access to information supports

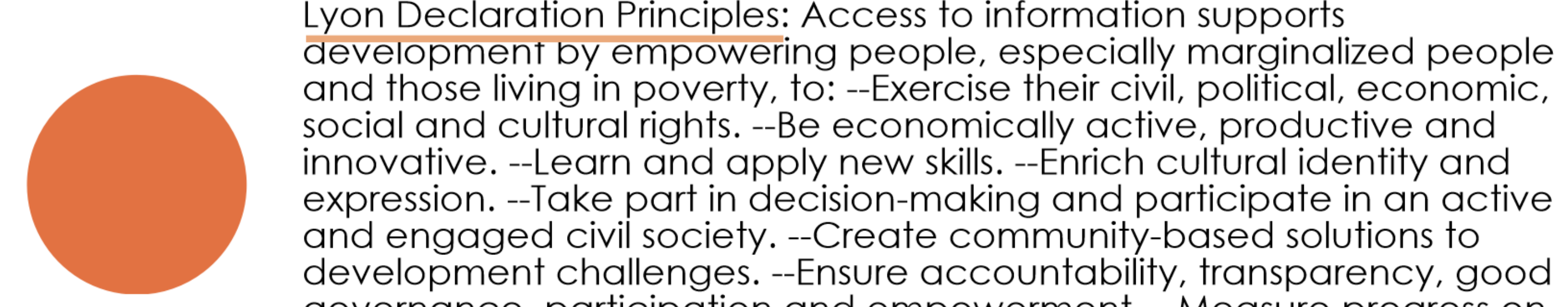
development challenges. --Ensure accountability transparency, good governance, participation and empowerment. --Measure prog
public and private commitments on sustainable development.

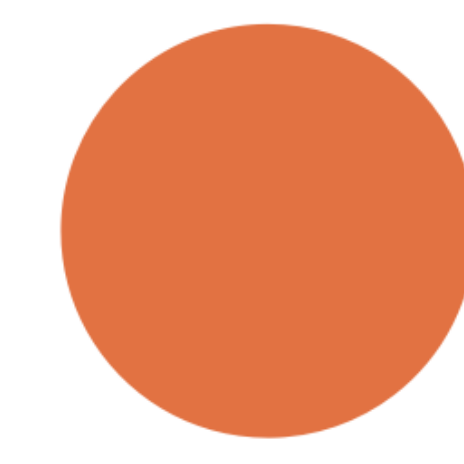

IFLA continues to engage in the negotiations leading up to the UN's

Scheeder spoke at the June 24,2015, "6th meeting -- Gonna Assembly, Intergovernmental negotiations on the UN post-2015 information in the Zero Draft. IFLA also encourages its members and partners to engage in their home countries' national development plans to ensure that access to information and libraries are recognized as vital components of a democratic society. IFLA
provides an Advocacy Toolkit with background on the issues and
practical advice on now to set up meetings with government

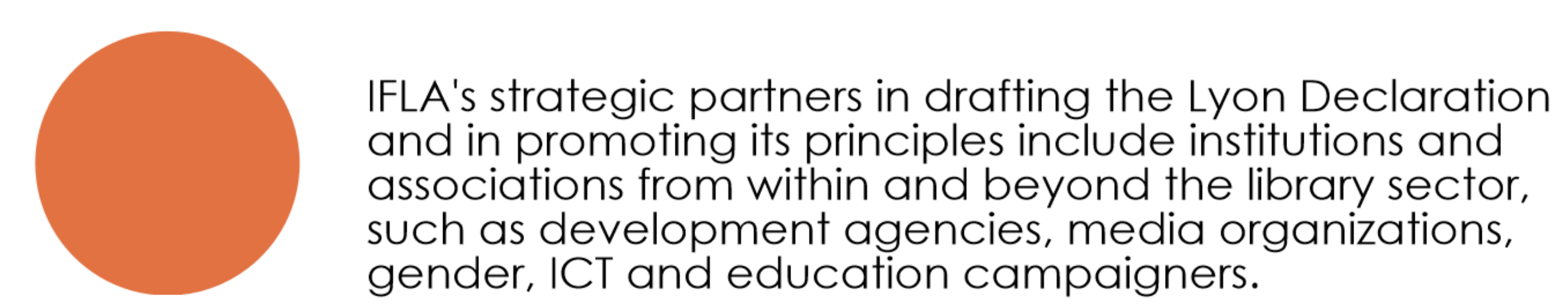
such as development agencies, media organ

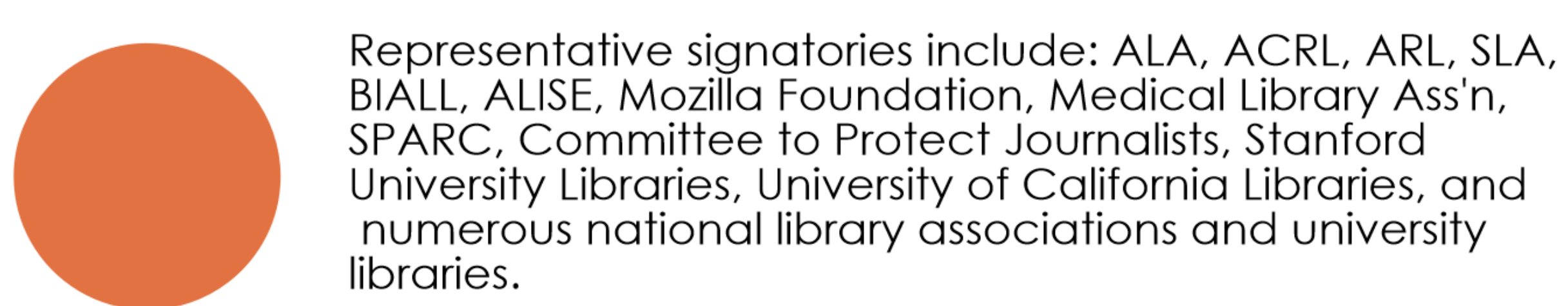
numerous

All's Executive Board voted in November. 2014 for AALL to add its name to the growing list of signatories.

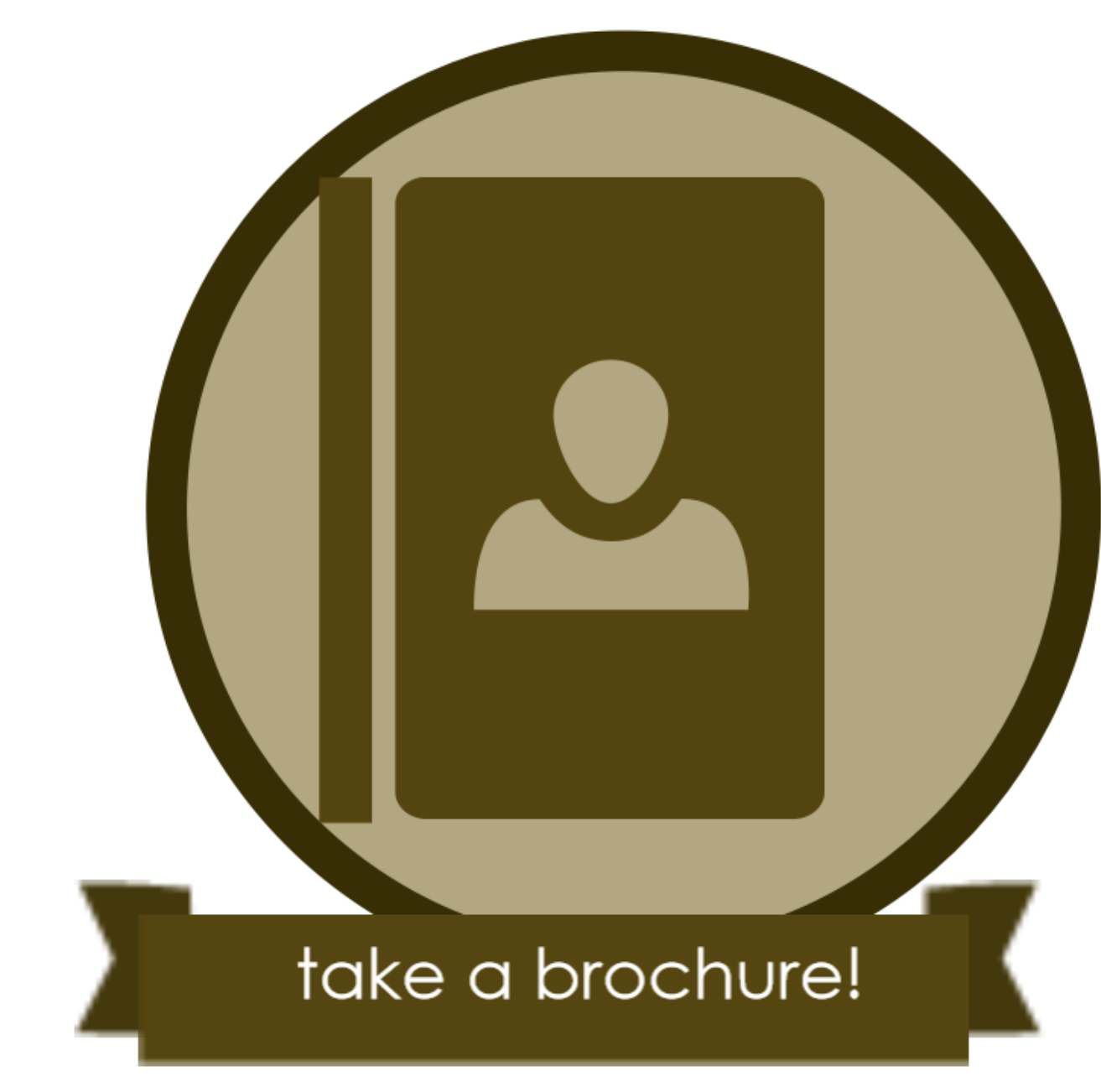

WHATIS IFLA?

A (n) independ a novernmental, proming orgatizan with over 1400 individuall) in 150 countries.

Other IFLA topics of interest to law government documents, copyid
and international standards

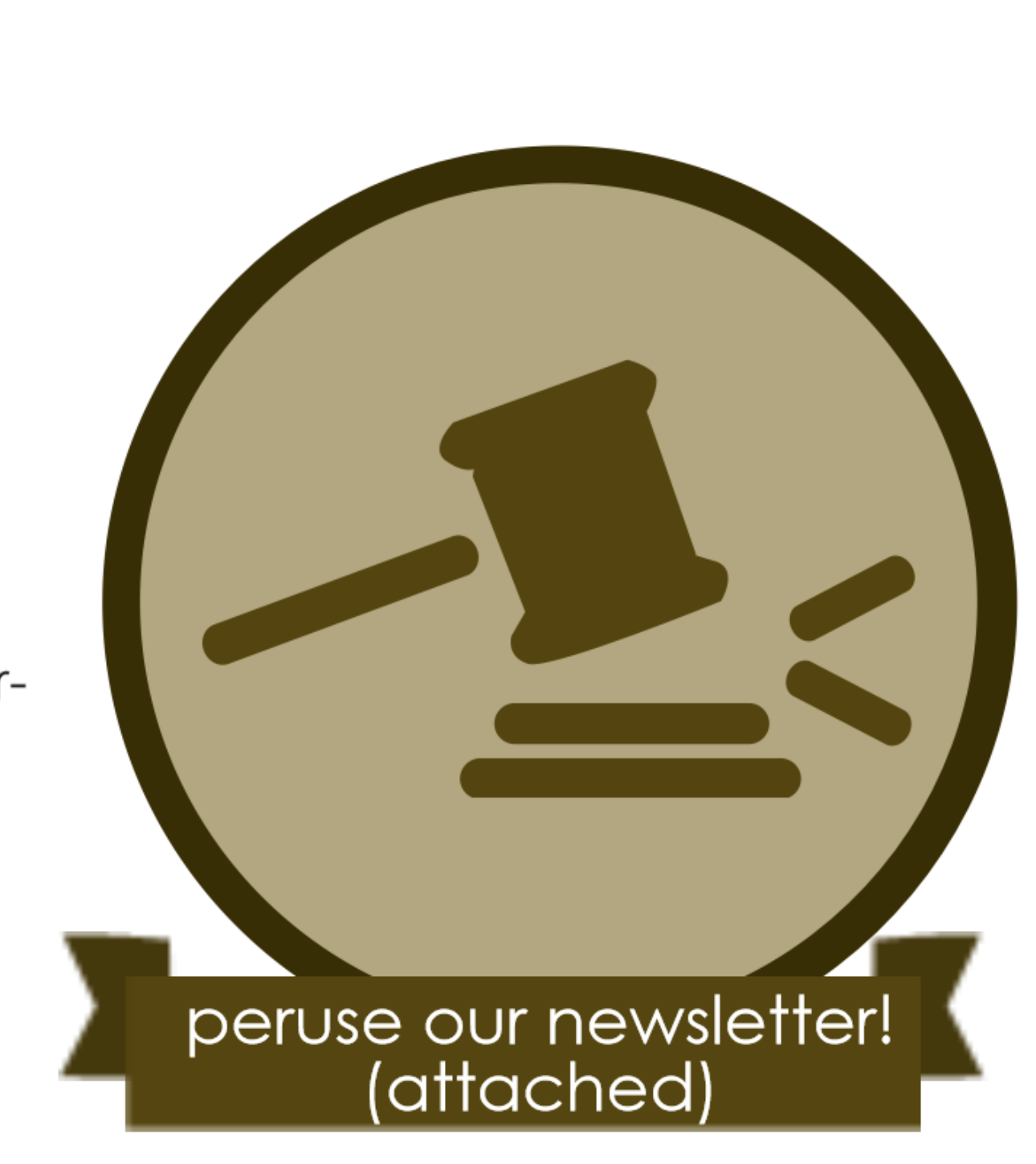

LAWLIBRARIES SECTION

- promotes understanding and
coperation among law libraries, and

importance of law libraries to the world;

of new law libraries, with a particular

-fosters the profession of law librarianship

worldwide;

-provides leadership in the field of legal information policy, recognizing that equitable and permanent public acces
to authentic legal information is a
necessary requirement for a just and

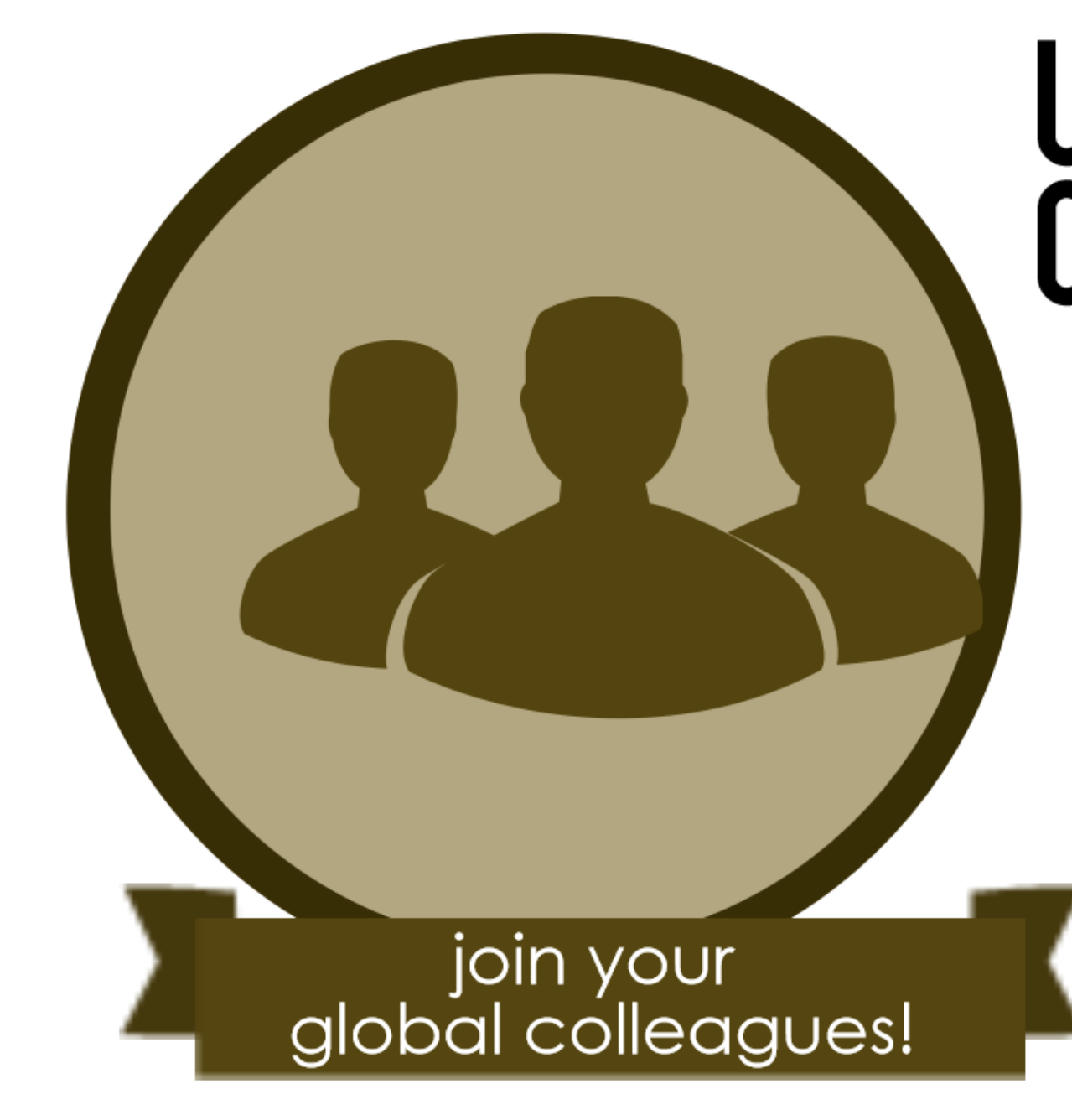

UPCOMING IFLA CONFERENCES

Join us at IFLA's World Library and Informatio Congress:

IFLA 2015: Cape Town South Africa

IFLA 2010
Ohio! 